\title{
Epidemiology in History
}

\section{The Origins and Early Evolution of Epidemiologic Research in Cardiovascular Diseases: A Tabular Record of Cohort and Case-Control Studies and Preventive Trials Initiated From 1946 to 1976}

\author{
Henry Blackburn* \\ * Correspondence to Dr. Henry Blackburn, Division of Epidemiology, University of Minnesota School of Public Health, 1300 S. \\ Second Street, Minneapolis, MN 55454 (e-mail: black002@umn.edu).
}

Initially submitted March 3, 2018; accepted for publication August 8, 2018.

\begin{abstract}
This article serves as a ready reference guide to the pioneering formal studies in cardiovascular disease (CVD) epidemiology initiated during 3 decades of the subject's evolution into an established academic field that contributed to the public health. The article is not intended to be a history of CVD epidemiology or an editorial about its significance. The appended tables include the titles and starting dates of the early studies, the names of their principal investigators, and references to a single defining article from each. The early observational studies of CVD epidemiology provided a widely useful CVD risk-factor paradigm. The early clinical trials justified the more definitive preventive trials of the 1980 s and beyond. This early research in populations, along with others in clinics and laboratories, led to greater understanding of the causes of CVD, to a vigorous practice of preventive cardiology, and to national policy and programs of health promotion, all of which were coincident with a 50-year decline in CVD mortality rates.
\end{abstract}

cardiovascular disease; case-control studies; cohort studies; trials

Abbreviation: CVD, cardiovascular disease.

The great and wonderful success story—not to say—saga—of CVD epidemiology-is rooted in the accumulated knowledge gained over a remarkably short space of time in a number of countries from an even larger number of studies. The wonder and fascination lies in having been able to build a solid, coherent, and powerful theory of causation as a starting point for preventive action.

-Frederick Epstein (1)

In a pioneering period of chronic disease epidemiologic research - from Gertler and White's (2) 1946 Harvard study of risk characteristics among 100 young coronary patients versus controls to cohort studies of varied groups in the United States, Britain, the European Continent, and Japan-a wave of cardiovascular disease (CVD) preventive research swept the world. These studies among populations, along with prevention research conducted in clinics and laboratories, were an enthusiastic and rapid response of the scientific community-mainly nonepidemiologists - to the epidemic of heart attacks that was recognized soon after World War II.
Absent an authoritative academic text on the history of CVD epidemiology, some documentation of the origins and early evolution of this new science, as well as of the community of investigators and institutions that nurtured it, may be found in modern literature (3-6). That history is also accessible from a dedicated archive and website of the University of Minnesota School of Public Health (7).

The tabular presentation herein is not, in itself, a history of CVD epidemiology; rather, it is a ready reference to the early literature that comprises that history. The tables ignore less formal but nonetheless influential historical elements upon which formal CVD epidemiology was built. The sources tabulated here exclude the following:

- Accounts of informal observations by medical "Marco Polos," that is, astute travelers who encountered people having apparently few CVD events in one place and populations with an apparently great CVD burden in another. Voyagers returned from foreign lands with new and researchable ideas about possible causes of the apparent cultural differences. A critical 
Table 1. Cohort Studies Initiated From 1946 to 1976

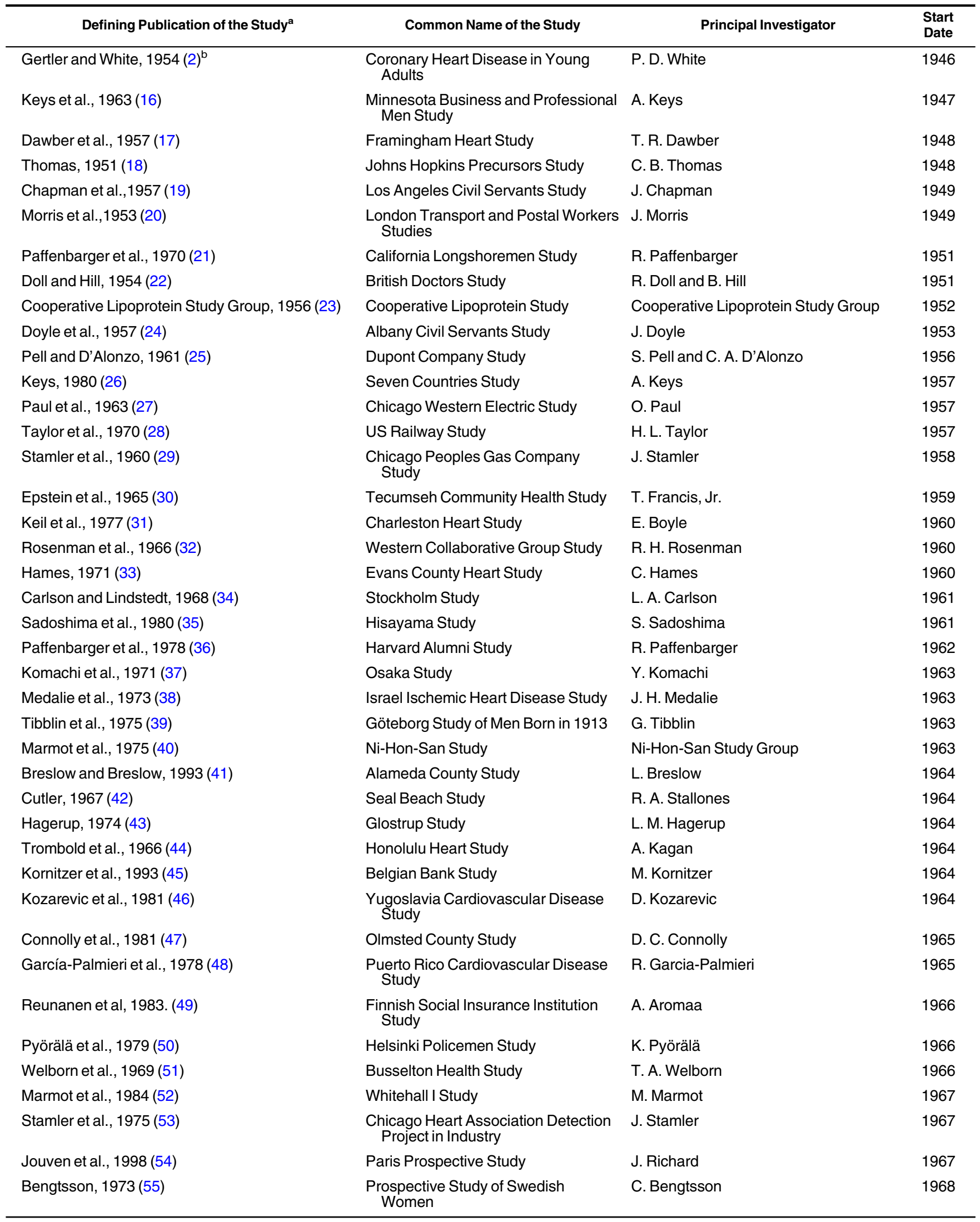


Table 1. Continued

\begin{tabular}{lll}
\hline \multicolumn{1}{c}{ Defining Publication of the Study } & \multicolumn{1}{c}{ Common Name of the Study } & \multicolumn{1}{c}{$\begin{array}{c}\text { Start } \\
\text { Date }\end{array}$} \\
\hline Lannerstad et al., 1977 (56) & Malmö Study of Men Born in 1914 & O. Lannerstad \\
$\begin{array}{l}\text { The Lipid Research Clinics Program } \\
\text { Epidemiology Committee, 1979 (57) }\end{array}$ & $\begin{array}{c}\text { Lipid Research Clinics Population } \\
\text { Study }\end{array}$ & $\begin{array}{l}\text { The Lipid Research Clinics Program } \\
\text { Epidemiology Committee }\end{array}$ \\
Lauer et al., $1975(58)$ & Muscatine lowa Study & R. M. Lauer \\
Berenson et al., $1978(59)$ & Bogalusa Heart Study & G. Berenson \\
Hawthorne et al., $1995(60)$ & Paisley-Renfrew Study & V. M. Hawthorne \\
Holme et al., $1980(61)$ & Oslo Study (Cohort) & P. Leren \\
Schnohr et al., $1977(62)$ & Copenhagen City Heart Study & P. Schnohr \\
\hline
\end{tabular}

Abbeviation: Ni-Hon-San, Nippon, Honolulu, San Francisco.

${ }^{a}$ The references are those that either defined the particular study and called international attention to it or presented the first substantive results. They are usually neither the very first nor the summative or final study reports.

${ }^{b}$ This study in young coronary patients began in 1946 as a case-control study and is included here because it was later converted into a prospective study of the cohort that was followed for 25 years with pair-matched and unmatched controls.

few among these travelers recognized that such widely contrasting "natural experiments" indicated powerful environmental and behavioral influences on CVD and thus the potential for prevention (8).

- Salient clinical studies, such as a large case-series of coronary disease in the US armed forces by Yater et al. (9), and systematic comparisons of arterial pathology across cultures, such as the International Geopathological Study by Strong et al. (10) from New Orleans.

- Cross-sectional surveys of CVD risk factors and prevalence, either single or serial, in which individuals were not subsequently followed (and thus were not cohort studies).

This tabulation of articles from CVD epidemiologic studies initiated between 1946 and 1976 includes the following:

- Formal prospective studies among varied cohorts (Table 1) and experiments as prevention trials (Table 2). Case-control comparisons, so fruitful in cancer epidemiology, were uniquely uncommon in early CVD epidemiology and played no role in construction of the popular CVD risk profile. Here, for the sake of completeness and consistency, the entirety of early casecontrol literature for CVD is included in Table 3, comprising 3 articles, 2 of which were analyses from the Framingham Study. (Nested case-control comparisons have since come into substantial use in post hoc analyses, often of newer ideas about risk, carried out in long-term data bases of large cohort studies.)

\section{THE TABULATIONS}

Publications from early population studies and trials of CVD prevention initiated between 1946 and 1976 are catalogued here to facilitate pursuit of the historic beginnings of CVD epidemiology. "Initiation" refers to the approximate start of data collection in each study, which usually followed extensive planning, collaboration, and pilot studies. The tables are intended for use by students and scholars of CVD, public health, and the history of science. The publications chosen (1 per study) are those that either defined the particular study and called international attention to it or that presented the first substantive results. Therefore, the articles are often neither the very first nor the summative or final report from a given study.

A few of the earliest diet trials are labeled with a note indicating the studies were inadequately controlled, and thus their conclusions about diet effects were questionable. Those articles are included in this collection because of their impact at the time: They were led by noted investigators, they were published after review by prestigious journals, and their conclusions were widely, if erroneously, accepted.

\section{CONTEXT}

A remarkable element of this array of historical observational studies (Tables 1 and 3 ) is the overwhelming early adoption of cohort design, that is, a baseline survey to establish personal characteristics and CVD prevalence at entry, with follow-up observations of varied duration for rates of CVD events and deaths. This more expensive and "patient" cohort strategy was chosen over case-control design because of its strength and for its simplicity: It was a straightforward design readily understood by CVD investigators who had insufficient training or understanding of the complexities of case-control comparisons.

An additional strong feature of these early epidemiologic studies was the prominent use of whole or healthy population cohorts, thus providing greatest relevance to primary prevention. Another was the great variety of populations recruited. Study initiators used whatever population was at hand: an accessible organization, industry, school, or community. This variety of samples had positive implications for the generalizability of the several CVD risk characteristics that were consistently found.

\section{EVOLUTION}

Despite stumbling performance-frequently by the pioneering CVD experts who were untrained in epidemiology or trial 
Table 2. Prevention Trials Initiated From 1946 to 1976

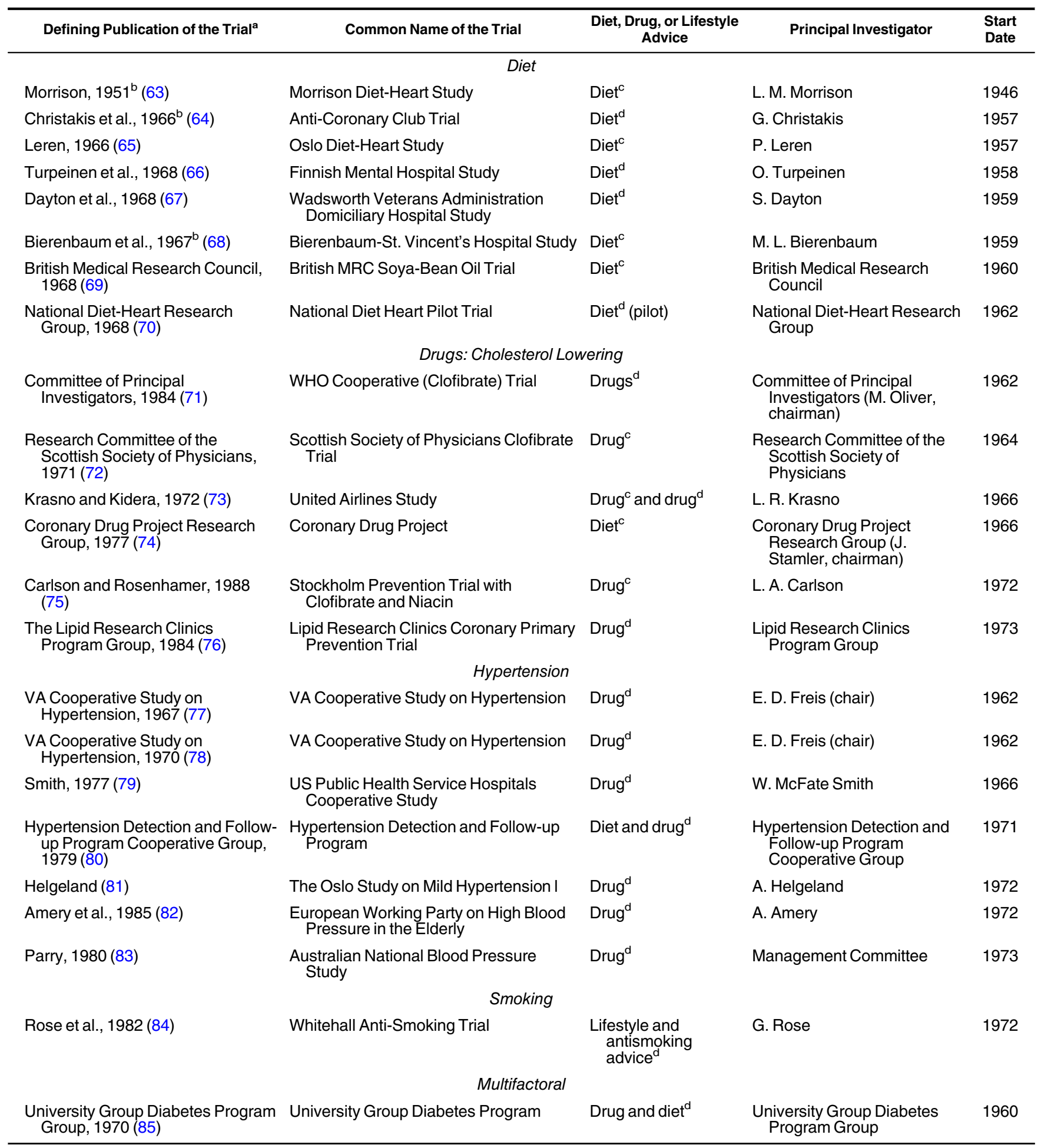


Table 2. Continued

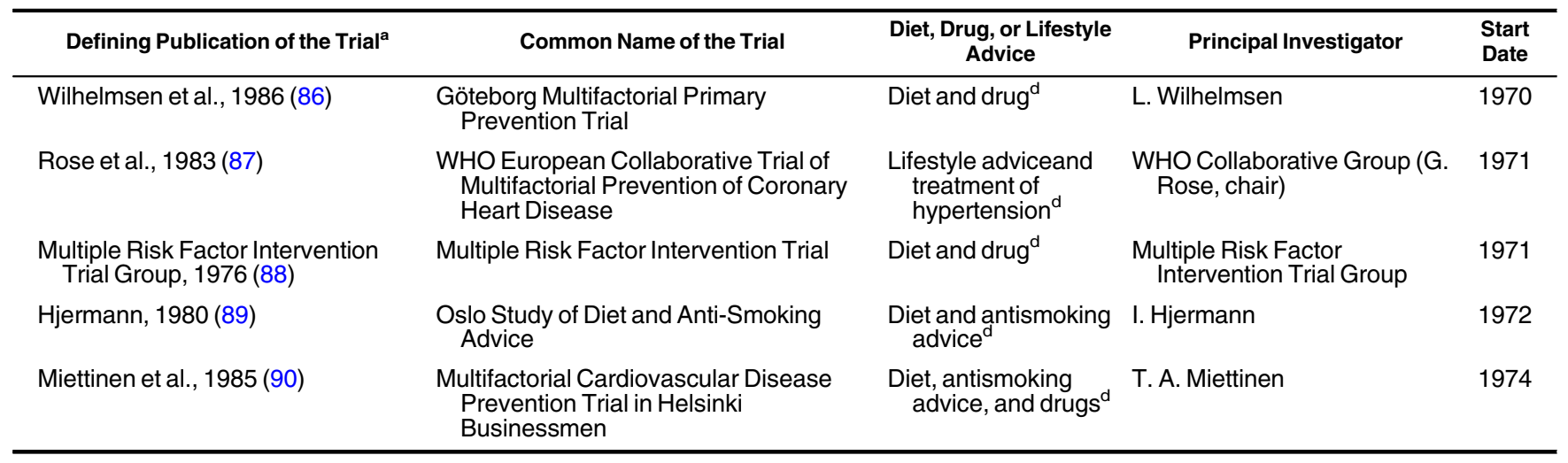

${ }^{a}$ The references are those that either defined the particular study and called international attention to it or presented the first substantive results. They are usually neither the very first nor the summative or final study reports.

${ }^{\mathrm{b}}$ Nonrandomized controls.

${ }^{\mathrm{C}}$ Secondary prevention.

d Primary prevention.

design - the magnitude, sophistication, and fruits of research on population rates and on risk of CVD advanced rapidly after World War II. The curiosity of the early investigators and the intense postwar period of prospective studies, particularly among healthy cohorts, established by the mid-1970s a risk-factor paradigm for CVD that proved universally useful in the research, practice, and policy of prevention. During 3 decades of combined, focused clinical, laboratory, and epidemiologic research from the mid-1940s to the mid-'70s, sufficient evidence was brought forward to provoke the greater systemic efforts required to better understand and modify the underlying disease processes of atherosclerosis and hypertension.

The combined enterprise of this early period led to greater acceptance, support, and research volume in CVD epidemiology, a prime stimulus for which was the advent of new policy at the US National Institutes of Health that soon followed by measures from the World Health Organization and various national heart foundations. Under pressure from and the guidance of expert recommendations from the science community (11-13), Theodore Cooper, Director of the National Heart and Lung Institute (now the National Heart, Lung, and Blood Institute), announced a broad US policy and program of CVD prevention at the 1971
Annual Scientific Sessions of the American Heart Association (14). This was promptly translated into new prospective studies, trials, and community education programs (on tobacco use, hypertension control, and diet and blood lipids), as well as a proliferation in teaching and practice of CVD epidemiology and preventive cardiology. The ultimate mission was to prevent CVD in the individual and among the population at large.

Beginning in the late 1960s and continuing today, CVD death rates have declined in many industrial countries; there have also been favorable trends in health knowledge and behavior and in cardiac care (3). The average decline in age-adjusted CVD mortality rate from its US peak in 1968 was 3\% per year for the decades 1968-1997 and 5\% per year from 1998 to 2008 (15). Similar rates of decline occurred in other industrial countries, with wide variations among the regions and ethnic groups of those countries.

Nevertheless, today much of the world is experiencing rapid socioeconomic development, with new exposures and behaviors accompanied by a scourge of mass obesity and metabolic diseases. Concerned scholars of this new epidemic should profit from the lessons of history reflected in these early reports, as well as from today's improved epidemiologic skills.

Table 3. Case-Control Studies Initiated From 1946 to 1976

\begin{tabular}{lllr}
\hline Defining Publication of the Study & \multicolumn{1}{c}{ Common Name of the Study } & \multicolumn{1}{c}{ Principal Investigator } & \multicolumn{1}{c}{ Dates of the Study } \\
\hline Gertler and White, $1954(2)^{b}$ & Coronary Heart Disease in Young Adults & P.D. White & $1946-1954$ \\
Friedman et al., 1966 (91) & Case-control versus cohort analysis in the Framingham Study & G. D. Friedman \\
Friedman et al., 1974 (92) & Case-Control Study of Standard Risk Factors & G. D. Friedman & 1964 \\
\hline
\end{tabular}

${ }^{a}$ The references are those that either defined the particular study and called international attention to it or presented the first substantive results. They are usually neither the very first nor the summative or final study reports.

${ }^{b}$ This study was converted to a prospective study of the cohort with both pair-matched and unmatched controls, then followed for $25 \mathrm{years}$. 


\section{ACKNOWLEDGMENTS}

Author affiliation: Division of Epidemiology, University of Minnesota School of Public Health, Minneapolis (Henry Blackburn).

This work was supported in part by grant $5 \mathrm{G} 13$ LM008214-02 from the US National Institutes of Health, Bethesda, Maryland; the Frederick Epstein Fund, Zurich, Switzerland; the Council on Epidemiology and Prevention of the American Heart Association, Dallas, Texas; and the International Society of Cardiology, Geneva, Switzerland.

I thank the Working Group on the History of

Cardiovascular Diseases, based at the Mailman School of Public Health, Columbia University, for helpful critique of this article.

Conflict of interest: none declared.

\section{REFERENCES}

1. Epstein F. From Seven Countries to MONICA: public health implications and future perspectives. Presented at European Society of Cardiology Working Group on Epidemiology and Prevention, Venice, Italy, April 24-26, 1994.

2. Gertler MM, White PD. Coronary Heart Disease in Young Adults: A Multidisciplinary Study. Cambridge, MA: Harvard University Press; 1954.

3. Marmot M, Elliott P, eds. Coronary Heart Disease Epidemiology: From Aetiology to Public to Health. 2nd ed. Oxford, United Kingdom: Oxford University Press; 1992.

4. Epstein FH. Cardiovascular disease epidemiology: a journey from the past into the future. Circulation. 1996;93(9): 1755-1764.

5. Oppenheimer GM. Profiling risk: the emergence of coronary heart disease epidemiology in the United States (1947-70). Int J Epidemiol. 2006;35(3):720-730.

6. Holland WW, Olson J, du V et al. The Development of Modern Epidemiology: Personal Reports From Those Who Were There. Oxford, United Kingdom: Oxford University Press; 2007.

7. University of Minnesota. Heart attack prevention: a history of cardiovascular disease epidemiology. http://www.epi.umn. edu/cvdepi/index.html. Updated October 15, 2012. Accessed September 15, 2018.

8. Blackburn H. 20th-Century "medical Marco Polos" in the origins of preventive cardiology and cardiovascular disease epidemiology. Am J Cardiol. 2012;109(5):756-767.

9. Yater WM, Traum AH, Brown WG, et al. Coronary artery disease in men eighteen to thirty-nine years of age: report of eight hundred sixty-six cases, four-hundred fifty with necropsy examination. Am Heart J. 1948;36(3):334-372.

10. Strong JP, McGill HC Jr, Tejada C, et al. The natural history of atherosclerosis: comparison of the early aortic lesions in New Orleans, Guatemala, and Costa Rica. Am J Pathol. 1958;34(4): 731-744.

11. Kannel WB, Doyle JT, Ostfeld AM, et al. Optimal resources for primary prevention of atherosclerotic diseases. Atherosclerosis Study Group. Circulation. 1984;70(1): 155A-205A.

12. National Institutes of Health. Arteriosclerosis: A Report by the National Heart and Lung Institute Task Force on Arteriosclerosis. Vol. 1. Washington, DC: National Institutes of Health; 1971. (US Department of Health, Education, and Welfare publication NIH 72-137).
13. International Society of Cardiology Research Committee Meeting at Makarska, September, 1963. Br Heart J. 1964; 26(4):558-565.

14. Cooper T. Arteriosclerosis. Policy, polity, and parity. Circulation. 1972;45(2):433-440.

15. National Heart, Lung, and Blood Institute. Morbidity \& Mortality: 2012 Chartbook on Cardiovascular, Lung, and Blood Diseases. Washington, DC: National Institutes of Health; 2012.

16. Keys A, Taylor HL, Blackburn H, et al. Coronary heart disease among Minnesota business and professional men followed fifteen years. Circulation. 1963;28:381-395.

17. Dawber TR, Moore FE, Mann GV. Coronary heart disease in the Framingham study. Am J Public Health Nations Health. 1957;47(4 pt 2):4-24.

18. Thomas CB. Observations on some possible precursors of essential hypertension and coronary artery disease. Bull Johns Hopkins Hosp. 1951;89(6):419-441.

19. Chapman JM, Goerke LS, Dixon W, et al. Measuring the risk of coronary heart disease in adult population groups. The clinical status of a population group in Los Angeles under observation for two to three years. Am J Public Health Nations Health. 1957;47(4 Pt 2):33-42.

20. Morris JN, Heady JA, Raffle PA, et al. Coronary heart disease and physical activity of work. Lancet. 1953;265(6795): 1053-1057.

21. Paffenbarger RS Jr, Laughlin ME, Gima AS, et al. Work activity of longshoremen as related to death from coronary heart disease and stroke. N Engl J Med. 1970;282(20): 1109-1114.

22. Doll R, Hill AB. The mortality of doctors in relation to their smoking habits: a preliminary report. Br Med J. 1954;1(4877): 1451-1455.

23. Gofman JW, Hanig M, Jones HB, et al. Evaluation of serum lipoprotein and cholesterol measurements as predictors of clinical complications of atherosclerosis: report of a cooperative study of lipoproteins and atherosclerosis. Circulation. 1956;14(4 part 2):691-742.

24. Doyle JT, Heslin AS, Hilleboe HE, et al. A prospective study of degenerative cardiovascular disease in Albany: report of three years' experience. I. Ischemic heart disease. Am J Public Health Nations Health. 1957;47(4 Pt 2):25-32.

25. Pell S, D'Alonzo CA. A three-year study of myocardial infarction in a large employed population. JAMA. 1961;175:463-470.

26. Keys A. Seven Countries. A Multivariate Analysis of Death and Coronary Heart Disease. Cambridge, MA: Harvard University Press; 1980.

27. Paul O, Lepper MH, Phelan WH, et al. A longitudinal study of coronary heart disease. Circulation. 1963;28:20-31.

28. Taylor HL, Blackburn H, Keys A, et al. Coronary heart disease in seven countries. IV. Five-year follow-up of employees of selected US railroad companies. Circulation. 1970;41(4 suppl):I20-I39.

29. Stamler J, Lindberg HA, Berkson DM, et al. Prevalence and incidence of coronary heart disease in strata of the labor force of a Chicago industrial corporation. J Chronic Dis. 1960;11: 405-420.

30. Epstein FH, Francis T Jr, Hayner NS, et al. Prevalence of chronic diseases and distribution of selected physiologic variables in a total community, Tecumseh, Michigan. Am J Epidemiol. 1965;81(3):307-322.

31. Keil JE, Tyroler HA, Sandifer SH, et al. Hypertension: effects of social class and racial admixture: the results of a cohort study in the black population of Charleston, South Carolina. Am J Public Health. 1977;67(7):634-639. 
32. Rosenman RH, Friedman M, Straus R, et al. Coronary heart disease in the Western Collaborative Group Study. A followup experience of two years. JAMA. 1966;195(2):86-92.

33. Hames CG. Evans County cardiovascular and cerebrovascular epidemiologic study. Introduction. Arch Intern Med. 1971; 128(6):883-886.

34. Carlson LA, Lindstedt S. The Stockholm prospective study. 1. The initial values for plasma lipids. Acta Med Scand Suppl. 1968;493:1-135.

35. Sadoshima S, Kurozumi T, Tanaka K, et al. Cerebral and aortic atherosclerosis in Hisayama, Japan. Atherosclerosis. 1980; 36(1):117-126.

36. Paffenbarger RS Jr, Wing AL, Hyde RT. Physical activity as an index of heart attack risk in college alumni. Am J Epidemiol. 1978;108(3):161-175.

37. Komachi Y, Iida M, Shimamoto T, et al. Geographic and occupational comparisons of risk factors in cardiovascular diseases in Japan. Jpn Circ J. 1971;35(2):189-207.

38. Medalie JH, Kahn HA, Neufeld HN et al. Five-year myocardial infarction incidence. II. Association of single variables to age and birthplace. J Chronic Dis. 1973;26(6):325-349.

39. Tibblin G, Wilhelmsen L, Werkö L. Risk factors for myocardial infarction and death due to ischemic heart disease and other causes. Am J Cardiol. 1975;35(4):514-522.

40. Marmot MG, Syme SL, Kagan A, et al. Epidemiologic studies of coronary heart disease and stroke in Japanese men living in Japan, Hawaii and California: prevalence of coronary and hypertensive heart disease and associated risk factors. Am J Epidemiol. 1975;102 (6): 514-525.

41. Breslow L, Breslow N. Health practices and disability: some evidence from Alameda County. Prev Med. 1993;22(1):86-95.

42. Cutler JL. Cerebrovascular disease in an elderly population. Circulation. 1967;36(3):394-399.

43. Hagerup LM. Coronary heart disease risk factors in men and women. From the population study in Glostrup, Denmark. Acta Med Scand Suppl. 1974;557:1-116.

44. Trombold JC, Moellering RC Jr, Kagan A. Epidemiological aspects of coronary heart disease and cerebrovascular disease: the Honolulu Heart Program. Hawaii Med J. 1966; 25(3): 231-234.

45. Kornitzer M, Dramaix M, Beriot I, et al. Twenty-five-year mortality follow-up in the Belgian Bank Study. Cardiology. 1993;82(2-3):153-171.

46. Kozarevic D, McGee D, Vojvodic N, et al. Serum cholesterol and mortality: the Yugoslavia Cardiovascular Disease Study. Am J Epidemiol. 1981;114(1):21-28.

47. Connolly DC, Oxman HA, Nobrega FT, et al. Coronary heart disease in residents of Rochester, Minnesota, 1950-1975. I. Background and study design. Mayo Clin Proc. 1981;56(11): 661-664.

48. García-Palmieri MR, Costas R Jr, Cruz-Vidal M, et al. Urbanrural differences in coronary heart disease in a low incidence area: the Puerto Rico Heart Study. Am J Epidemiol. 1978; 107(3):206-215.

49. Reunanen A, Aromaa A, Pyörälä K, et al. The Social Insurance Institution's coronary heart disease study. Baseline data and 5year mortality experience. Acta Med Scand Suppl. 1983;213: $1-120$.

50. Pyörälä K, Savolainen E, Lehtovirta E, et al. Glucose tolerance and coronary heart disease: Helsinki policemen study. J Chronic Dis. 1979;32(11-12):729-745.

51. Welborn TA, Cumpston GN, Cullen KJ, et al. The prevalence of coronary heart disease and associated factors in an Australian rural community. Am J Epidemiol. 1969;89(5): $521-536$.
52. Marmot MG, Shipley MJ, Rose G. Inequalities in deathspecific explanations of a general pattern? Lancet. 1984; 323(8384):1003-1006.

53. Stamler J, Rhomberg P, Schoenberger JA, et al. Multivariate analysis of the relationship of seven variables to blood pressure: findings of the Chicago Heart Association Detection Project in Industry, 1967-1972. J Chronic Dis. 1975;28(10): 527-548.

54. Jouven X, Desnos M, Guerot C, et al. Predicting sudden death in the population: the Paris Prospective Study I. Circulation. 1999;99(15):1978-1983.

55. Bengtsson C. Ischaemic heart disease in women. A study based on a randomized population sample of women and women with myocardial infarction in Göteborg, Sweden. Acta Med Scand Suppl. 1973;549:1-128.

56. Lannerstad O, Sternby NH, Isacsson SO, et al. Effects of a health screening on mortality and causes of death in middleaged men. A prospective study from 1970 to 1974 of men in Malmö, born in 1914. Scand J Soc Med. 1977;5(3):137-140.

57. The Lipid Research Clinics Program Epidemiology Committee. Plasma lipid distributions in selected North American populations: the Lipid Research Clinics Program Prevalence Study. Circulation. 1979;60(2):427-439.

58. Lauer RM, Connor WE, Leaverton PE, et al. Coronary heart disease risk factors in school children: the Muscatine study. J Pediatr. 1975;86(5):697-706.

59. Berenson GS, Foster TA, Frank GC, et al. Cardiovascular disease risk factor variables at the preschool age. The Bogalusa Heart Study. Circulation. 1978;57(3):603-612.

60. Hawthorne VM, Watt GC, Hart CL, et al. Cardiorespiratory disease in men and women in urban Scotland: baseline characteristics of the Renfrew/Paisley (midspan) study population. Scott Med J. 1995;40(4):102-107.

61. Holme I, Helgeland A, Hjermann I, et al. Four and two-thirds years incidence of coronary heart disease in middle-aged men: the Oslo Study. Am J Epidemiol. 1980;112(1):149-160.

62. Schnohr P, Jensen G, Nyboe J, et al. The Copenhagen City Heart Study. A prospective cardiovascular population study of 20,000 men and women. Ugeskr Laeger. 1977;139(32): 1921-1923.

63. Morrison LM. Reduction of mortality rate in coronary atherosclerosis by a low cholesterol-low fat diet. Am Heart $J$. 1951;42(4):538-545.

64. Christakis G, Rinzler SH, Archer M, et al. The anti-coronary club: a dietary approach to the prevention of coronary heart disease: a seven-year report. Am J Public Health Nations Health. 1966;56(2):299-314.

65. Leren P. The effect of plasma cholesterol lowering diet in male survivors of myocardial infarction. A controlled clinical trial. Acta Med Scand Suppl. 1966;466:1-92.

66. Turpeinen O, Miettinen M, Karvonen MJ, et al. Dietary prevention of coronary heart disease: long-term experiment. I. Observations on male subjects. Am J Clin Nutr. 1968;21(4): 255-276.

67. Dayton S, Pearce ML, Goldman H, et al. Controlled trial of a diet high in unsaturated fat for prevention of atherosclerotic complications. Lancet. 1968;292(7577):1060-1062.

68. Bierenbaum ML, Green DP, Florin A, et al. Modified-fat dietary management of the young male with coronary disease. A five-year report. JAMA. 1967;202(13):1119-1123.

69. British Medical Research Council. Controlled trial of soyabean oil in myocardial infarction. Lancet. 1968;292(7570): 693-700.

70. National Diet-Heart Research Group. The National Diet-Heart Study final report. Circulation. 1968;37(3 suppl):I1-I428. 
71. Committee of Principal Investigators. WHO cooperative trial on primary prevention of ischaemic heart disease with clofibrate to lower serum cholesterol: final mortality follow-up. Lancet. 1984;324(8403):600-604.

72. Research Committee of the Scottish Society of Physicians. Ischaemic heart disease: a secondary prevention trial using clofibrate. Br Med J. 1971;4(5790):775-784.

73. Krasno LR, Kidera GJ. Clofibrate in coronary heart disease. Effect on morbidity and mortality. JAMA. 1972;219(7):845-851.

74. Stamler J. The coronary drug project: findings with regard to estrogen, dextrothyroxine, clofibrate and niacin. Adv Exp Med Biol. 1977;82:52-75.

75. Carlson LA, Rosenhamer G. Reduction of mortality in the Stockholm Ischaemic Heart Disease Secondary Prevention Study by combined treatment with clofibrate and nicotinic acid. Acta Med Scand. 1988;223(5):405-418.

76. Lipid Research Clinics Program. The Lipid Research Clinics Coronary Primary Prevention Trial results. I. Reduction in incidence of coronary heart disease. JAMA. 1984;251(3):351-364.

77. Veterans Administration Cooperative Study Group on Antihypertensive Agents. Effects of treatment on morbidity in hypertension. Results in patients with diastolic blood pressures averaging 115 through $129 \mathrm{~mm} \mathrm{Hg}$. JAMA. 1967;202(11): 1028-1034.

78. Veterans Administration Cooperative Study Group on Antihypertensive Agents. Effects of treatment on morbidity in hypertension II. Results in patients with diastolic blood pressure averaging 90 through $114 \mathrm{~mm} \mathrm{Hg.} \mathrm{JAMA.} \mathrm{1970;}$ 213(7):1143-1152.

79. Smith WM. Treatment of mild hypertension: results of a ten-year intervention trial. Circ Res. 1977;40(5 suppl 1): I98-I105.

80. Hypertension Detection and Follow-up Program Cooperative Group. Five-year findings of the hypertension detection and follow-up program. I. Reduction in mortality of persons with high blood pressure, including mild hypertension. JAMA. 1979;242(23):2562-2571.

81. Helgeland A. Treatment of mild hypertension: a five-year controlled drug trial. The Oslo Study. Am J Med. 1980;69(5):725-732.
82. Amery A, Birkenhäger W, Brixko P, et al. Mortality and morbidity results from the European Working Party on High Blood Pressure in the Elderly trial. Lancet. 1985;325(8442): 1349-1354.

83. Parry CA. The Australian therapeutic trial in mild hypertension. Lancet. 1980;316(8191):425.

84. Rose G, Hamilton PJ, Colwell L, et al. A randomized controlled trial of anti-smoking advice: 10 -year results. J Epidemiol Community Health. 1982;36(2):102-108.

85. Meinert CL, Knatterud GL, Prout TE, et al. A study of the effects of hypoglycemic agents on vascular complications in patients with adult-onset diabetes. II. Mortality results. Diabetes. 1970;19(suppl):789-830.

86. Wilhelmsen L, Berglund G, Elmfeldt D, et al. The multifactor primary prevention trial in Göteborg, Sweden. Eur Heart J. 1986;7(4):279-288.

87. Rose G, Heller RF, Pedoe HT, et al. Heart disease prevention project: a randomized controlled trial in industry. $\mathrm{Br} \mathrm{Med} \mathrm{J}$. 1980;280(6216):747-751.

88. Multiple Risk Factor Intervention Trial Group. The Multiple Risk Factor Intervention Trial (MRFIT). A national study of primary prevention of coronary heart disease. JAMA. 1976; 235(8):825-827.

89. Hjermann I. Smoking and diet intervention in healthy coronary high risk men. Methods and 5-year follow-up of risk factors in a randomized trial. The Oslo Study. J Oslo City Hosp. 1980; 30(1):3-17.

90. Miettinen TA, Huttunen JK, Naukkarinen V, et al. Multifactorial primary prevention of cardiovascular disease in middle-aged men. Risk factor changes, incidence and mortality. JAMA. 1985;254(15):2097-2102.

91. Friedman GD, Kannel WB, Dawber TR. Comparison of prevalence, case-history and incidence data in assessing the potency of risk factors in coronary heart disease. Am J Epidemiol. 1966;83(2):366-378.

92. Friedman GD, Klatsky AL, Siegelaub AB. Kaiser-Permanente epidemiologic study of myocardial infarction. Study design and results for standard risk factors. Am J Epidemiol. 1974; 99(2):101-116. 